\title{
Influence of bryophyte biomass and organic matter quantity on the abundance and richness of oligochaetes in forest streams with different phytophysiognomies in southeastern Brazil
}

\author{
Luciana FALCI THEZA RODRIGUES, ${ }^{*}$ Felipe SILVEIRA LEITE, Roberto DA GAMA ALVES
}

Laboratory of Benthic Invertebrates, Department of Zoology, Institute of Biological Sciences, Federal University of Juiz de Fora, José Lourenço Kelmer, s/n, Campus Universitário, 36036-900, Juiz de Fora, MG, Brazil

*Corresponding author: biofalci@hotmail.com

\begin{abstract}
Aquatic oligochaetes can be found associated with different types of substrates; including bryophytes (mosses and liverworts) adhered to stones in lotic ecosystems. However, little information is available on the association between oligochaetes and bryophytes in tropical region. Therefore, the aims of this study were: to investigate whether the assemblages of oligochaetes respond to variation in the biomass of bryophytes and quantity of particulate organic matter (POM) present on these plants; verify differences in the composition of oligochaetes in streams flowing through areas with two phytophysiognomies (rocky field and seasonal semideciduous forest). The samples were collected from five first-order streams in the southeast of the state of Minas Gerais. Six samples of bryophytes adhered to stones were obtained from each stream. A total of 1586 oligochaetes were collected and 11 taxa were identified, belonging to the families Naididae and Enchytraeidae. The most abundant taxa were Bothrioneurum (37.95\%) and Enchytraeidae (33.01\%). A positive relation was observed between oligochaete abundance and POM in two streams (Ibitipoca I and Ibitipoca III) and a positive relation was found between oligochaete abundance and bryophyte biomass in one stream (Ibitipoca I). The composition of the fauna varied within and between the phytophysiognomies studied. The results show that the oligochaetes find favorable conditions to establish themselves in bryophytes, evidencing the ecological importance of these plants as habitat for invertebrates.
\end{abstract}

Key words: Atlantic forest; Enchytraeidae; liverwort; lotic systems; mosses; Naididae.

Received: June 2015. Accepted: January 2016.

\section{INTRODUCTION}

The bryophytes associated with stones in low-order lotic environments accumulate particulate organic matter (Habdija et al., 2004) and are used as substrate for colonization of periphyton (Stream Bryophyte Group, 1999), providing food and shelter against the water current (Rosa et al., 2011, 2013; Rodrigues et al., 2013) and refuge from predators (Glime and Clemons, 1972; Parker et al., 2007; Alvarez and Peckarsky, 2013) for various species of aquatic invertebrates. Several studies (Percival and Whitehead, 1929; Suren, 1993; Linhart et al., 2002; Tokeshi and Arakaki, 2012) have shown that these plants contribute to the dimensional complexity of the habitat within the stream flow, because they increase the surface area that can be colonized, resulting in a positive variation in the density and diversity of invertebrates.

The Oligochaeta are among the most diverse invertebrates that can be found in bryophytes (Gorni and Alves, 2007; Rodrigues et al., 2013b). Their presence is positively related to the biomass of these plants and the quantity of particulate organic matter retained among the phyllids and caulids (Suren, 1991; Suren and Winterboun, 1992; Linhart et al., 2002). The Oligochaeta species that colonize bryophytes are for the most part those present in the sediment of streams. In different phytophysiognomies, for example, streams can differ greatly regarding the morphology, sediment granulometry and type of plant matter that enters the beds. Therefore, the fauna present is a reflection of the local environmental conditions. In Brazil, specific studies of the oligochaete fauna associated with bryophytes are still rare, with the exceptions being the works of Gorni and Alves (2007) and Rodrigues et al. (2013b). Also, Rosa et al. (2011) investigated macroinvertebrates in bryophytes and also reported the presence of oligochaetes, with the most abundant family being Naididae.

The aim of this study was to learn the composition and structure of the assemblages of aquatic oligochaetes associated with bryophytes in first-order streams, to find out whether these invertebrates respond to the variation in the quantity of particulate organic matter retained in these plants and the different phytophysiognomies through which the streams flow. For this purpose, we tested the following hypotheses: i) habitats with larger bryophyte biomass contain a greater quantity of particulate organic matter, and consequently, greater abundance and richness of oligochaetes; and ii) the composition of the oligochaete fauna associated with bryophytes is distinct between 
streams located in different phytophysiognomies (seasonal semideciduous forest and rocky field).

\section{METHODS}

\section{Study area}

The study was conducted in two remnant Atlantic Forest areas in the state of Minas Gerais (southeastern Brazil) with different phytophysiognomies: Particular areaFazenda Floresta $\left(21^{\circ} 43^{\prime}\right.$ to $21^{\circ} 44^{\prime} \mathrm{S}$ and $43^{\circ} 16^{\prime}$ to $43^{\circ} 17^{\prime} \mathrm{W}$ - Juiz de Fora), where we selected two streams in an area of seasonal semideciduous forest (Floresta I and II), located at altitude between 800 and $890 \mathrm{~m}$; and Ibitipoca State Park $\left(21^{\circ} 40^{\prime}\right.$ to $21^{\circ} 43^{\prime} \mathrm{S}$ and $43^{\circ} 52^{\prime}$ to $43^{\circ} 54^{\prime} \mathrm{W}$ - Lima Duarte), with altitude from 1300 to 1400 $\mathrm{m}$, where we selected two streams flowing through rocky fields (Ibitipoca I and III) and one stream in a seasonal semideciduous forest fragment (Ibitipoca II).

Rocky field areas are characterized for having sandy soils (spodosols), with predominance of grasses, bushes and trees. The vegetation is typically xeromorphic due to the oligotrophy and acidity of the soil and water restrictions (Rapini et al., 2008). In Ibitipoca State Park, this phytophysiognomy includes gentle slopes with sandy/stony soil, rocky outcrops with steep slopes, mountain tops and swampy lowlands. In wetter areas near watercourses, it is common to find rocks covered by lichens and mosses. On the other hand, semideciduous seasonal forest areas are characterized by vegetation with an arboreal, arbustive and herbaceous strata, where the trees and bushes shed part of their leaves during the dry season, thus acting to regulate the water balance in the two climate seasons (dry and rainy). Argissols and latossols are the main soil types related to this type of forest (Dias et al., 2002).

The five streams sampled (Tab. 1) have well preserved riparian vegetation, without influence of human activities. The sediment in the streams located in the seasonal semideciduous forest areas consisted by coarse (58\%), medium $(34 \%)$ and fine $(6 \%)$ sand. The sediment in streams located in the rocky field areas were composed mainly by coarse
(83\%) sand, follow by medium (15\%) and fine (5\%) sand. All streams had well oxygenated water with low electrical conductivity, characteristic of preserved streams. The streams at higher altitudes had cooler water.

\section{Sampling}

In each stream, along a stretch of about $300 \mathrm{~m}$, we sampled six stones with approximate diameter of $20 \mathrm{~cm}$ that were fixed in the bed and totally or partially covered by bryophytes. The approximate distance between the stones was $40 \mathrm{~m}$ and all were collected in areas of riffles. A metal structure measuring 10x10 cm was placed over each stone, about 1 to $2 \mathrm{~cm}$ above the water surface, and the bryophytes were scraped with a spatula, placed individually in plastic jars and fixed in a $4 \%$ formaldehyde solution. The samples were gathered in May-July 2010.

In the laboratory, the bryophytes were carefully washed in running tap water over a sieve with mesh of 53 $\mu \mathrm{m}$ to remove the fauna and retained particulate matter. This material was sorted under a stereoscopic microscope and the oligochaetes were preserved in $70 \%$ alcohol. The bryophytes were dried in an oven at $60^{\circ} \mathrm{C}$ for $48 \mathrm{~h}$ and weighed on a precision balance $(0.1 \mathrm{mg})$ to calculate the biomass $(\mathrm{g})$. The same procedure was applied to the particulate matter, which was then incinerated in a muffle furnace at $550^{\circ} \mathrm{C}$ for $4 \mathrm{~h}$ to obtain the quantity of organic matter $(\mathrm{g})$, calculated by the difference between the initial weight (before burning) and the final weight (after burning). For identification of the oligochaete species, slides were prepared of the samples stained with lactophenol, as described by Brinkhurst (1971). The slides were examined under a light microscope to identify the oligochaetes to the lowest taxonomic level possible, according to Righi (1984) and Brinkhurst and Marchese (1989), using the updated nomenclature proposed by Reynolds and Wetzel (2014). The bryophytes were identified by specialists using the works of Frahm (1991), Sharp et al. (1994), Buck (1998), Gradstein and Costa (2003) and Pursell (2007) as references.

Tab. 1. Geographic localization, mean and standard deviation of limnological variables of the streams in Fazenda Floresta and Ibitipoca State Park, Minas Gerais, Brasil.

\begin{tabular}{|c|c|c|c|c|c|}
\hline & Coordinates & $\begin{array}{c}\text { Water } \\
\text { temperature }\left({ }^{\circ} \mathrm{C}\right)\end{array}$ & Oxygen $\left(\mathrm{mgL}^{-1}\right)$ & $\mathrm{pH}$ & $\begin{array}{l}\text { Conductivity } \\
\left(\mu \mathrm{Scm}^{-1}\right)\end{array}$ \\
\hline Floresta I & $21^{\circ} 44^{\prime} 7 ” S 43^{\circ} 18^{\prime} 2^{\prime \prime} \mathrm{W}$ & $18.5 \pm 0.10^{\mathrm{a}}$ & $10.8 \pm 0.90^{\mathrm{a}}$ & $8.23 \pm 0.57^{\mathrm{a}}$ & $21.16 \pm 7.59^{\mathrm{a}}$ \\
\hline Floresta II & $21^{\circ} 44^{\prime} 59^{\prime \prime} \mathrm{S} 43^{\circ} 17^{\prime} 28^{\prime \prime} \mathrm{W}$ & $18.3 \pm 0.26^{\mathrm{a}}$ & $11.07 \pm 0.66^{\mathrm{a}}$ & $8.12 \pm 0.52^{\mathrm{a}}$ & $16.60 \pm 1.60^{\mathrm{a}}$ \\
\hline Ibitipoca I & $21^{\circ} 42^{\prime} 11^{\prime \prime S} 3^{\circ} 53^{\prime} 34^{\prime \prime} \mathrm{W}$ & $14.4 \pm 0.17^{\mathrm{b}}$ & $10.83 \pm 0.05^{\mathrm{a}}$ & $7.60 \pm 0.26^{\mathrm{a}}$ & $11.10 \pm 0.96^{\mathrm{a}}$ \\
\hline Ibitipoca II & $21^{\circ} 42^{\prime} 25^{\prime \prime} \mathrm{S} 43^{\circ} 53^{\prime} 9^{\prime \prime} \mathrm{W}$ & $15.2 \pm 1.00^{\mathrm{b}}$ & $11.06 \pm 0.90^{\mathrm{a}}$ & $7.66 \pm 0.30^{\mathrm{a}}$ & $16.63 \pm 5.60^{\mathrm{a}}$ \\
\hline Ibitipoca III & $21^{\circ} 42^{\prime} 16^{\prime \prime} \mathrm{S} 43^{\circ} 53^{\prime} 13^{\prime \prime} \mathrm{W}$ & $14.08 \pm 0.80^{\mathrm{b}}$ & $11.0 \pm 0.60^{\mathrm{a}}$ & $7.60 \pm 0.20^{\mathrm{a}}$ & $13.90 \pm 4.70^{\mathrm{a}}$ \\
\hline
\end{tabular}

Different letters in the first column means that the values are significantly different $(P<0.05)$. 


\section{Data analysis}

The assemblages of oligochaetes were analyzed to determine the total abundance and taxonomic richness. Each bryophyte was considered a sample unit and each stream was considered a replicate. For the statistical analyses, the data on fauna were tested for normality (Shapiro-Wilk test) and homogeneity of the variance (Levene test) $(\alpha=0.05)$.

To check for differences in bryophyte biomass, quantity of particulate organic matter (POM), total abundance and richness of oligochaetes between streams, we used analysis of variance- one way ANOVA (or the KruskalWallis test for data without normal distribution). The values of abundance and richness were transformed in log $(\mathrm{x}+1)$. We used simple linear regression to test the relations: bryophyte biomass and POM; abundance and POM; abundance and bryophyte biomass; richness and POM; and richness and bryophyte biomass. We also used simple linear regression to check the relation between the abundance of oligochaetes and richness of bryophyte families and richness of oligochaetes and richness of bryophytes families. These tests were performed in Statistica program (Statsoft, 2004).

To test our second hypothesis, we applied the nonparametric Multi-Response Permutation Procedure (MRPP) to verify differences in the composition of taxa between the streams in the two phytophysiognomies studied, employing the PC-ORD program (McCune and Mefford, 2006).

\section{RESULTS}

We identified 1586 oligochaetes, belonging to the families Naididae and Enchytraeidae (Tab. 2). The most abundant taxa were Bothrioneurum (37.95\%) and Enchytraeidae $(33.1 \%)$. The Naididae specimens belonged to the subfamilies Naidinae (1.88\%), Pristininae (41.38\%) and Rhyacodrilinae (56.74\%), with Pristininae being the most diverse, containing eight species

We also identified 17 families of bryophytes, of which the most representative were Pilotrichaceae Kindb. (moss), Aneuraceae H. Klinggr. (liverwort) and Plagiochilaceae Müll. Frib. \& Herzog (liverwort). We recorded 30 taxa (genera or species) of bryophytes, and in general each sample contained more than one species. In the Floresta I stream, only one species was found, while Ibitipoca I stream had the greatest species richness $(S=12)$, of which eight were only found in this stream. There was no relation between the abundance of oligochaetes and richness of bryophyte families $\left(\mathrm{F}=0.534 ; \mathrm{P}=0.517 ; \mathrm{r}^{2}=0.151\right)$ or between the richness of oligochaetes and richness of bryophyte families $\left(\mathrm{F}=0.417 ; \mathrm{P}=0.564 ; \mathrm{r}^{2}=0.122\right)$. The oligochaete abundance was highest in Ibitipoca I and III streams $(\mathrm{df}=4 ; \mathrm{H}=15.130 ; \mathrm{P}=0.004)$ while the taxonomic richness was greatest in Ibitipoca II and III streams $(\mathrm{df}=4$; $\mathrm{F}=4.091 ; \mathrm{P}=0.018$ ) (Fig. 1 A,B). With respect to bryophyte biomass, Floresta I stream had the lowest values $(\mathrm{df}=4$; $\mathrm{F}=5.857 ; \mathrm{P}=0.001$ ) (Fig. $1 \mathrm{C}$ ). The total quantity of POM in the bryophyte samples differed only in relation to Floresta I stream (df=4; $\mathrm{F}=3.011 ; \mathrm{P}=0.037)$ (Fig. $1 \mathrm{D})$.

The linear regression results showed there was no significant relationship in the majority of the streams between the oligochaete abundance and POM quantity as well as between the oligochaete abundance and bryophyte biomass. The same applies to the oligochaete richness. The relationships were only significant for Ibitipoca I stream (except for richness $\mathrm{x}$ bryophyte biomass). Besides this, for Floresta I stream there was a significant relationship between POM quantity and bryophyte biomass, and for Ibitipoca III stream between oligochaete abundance and POM (Tab. 3). According to the MRPP results, the composition of oligochaetes varied within and between

Tab. 2. Numerical abundance of the taxa collected in the streams in Fazenda Floresta and Ibitipoca State Park, Minas Gerais, Brazil.

\begin{tabular}{|c|c|c|c|c|c|}
\hline & Floresta I & Floresta II & Ibitipoca I & Ibitipoca II & Ibitipoca III \\
\hline \multicolumn{6}{|l|}{ NAIDIDAE } \\
\hline \multicolumn{6}{|l|}{ Naidinae } \\
\hline Chaetogasther diastrophus (Gruithuisen, 1828) & - & - & - & 20 & - \\
\hline \multicolumn{6}{|l|}{ Pristininae } \\
\hline Pristina aequiseta Bourne, 1891 & - & - & - & - & 13 \\
\hline Pristina jenkinae (Stephenson, 1931) & 8 & 2 & - & 1 & - \\
\hline Pristina leidyi Smith, 1896 & - & - & - & - & 4 \\
\hline Pristina osborni (Walton, 1906) & - & 2 & 110 & 8 & 27 \\
\hline Pristina proboscidea Beddard, 1896 & - & - & - & - & 5 \\
\hline Pristina menoni (Aiyer, 1929) & - & - & 13 & - & - \\
\hline Pristina sp. 1 & 1 & 5 & - & 18 & - \\
\hline Pristina sp. 2 & - & - & 78 & - & 144 \\
\hline \multicolumn{6}{|l|}{ Rhyacodrilinae } \\
\hline Bothrioneurum & - & - & - & - & 602 \\
\hline ENCHYTRAEIDAE & 15 & 12 & 209 & 57 & 232 \\
\hline Total abundance & 24 & 21 & 410 & 104 & 1027 \\
\hline
\end{tabular}


the phytophysiognomies studied. As shown in Tab. 4, there was a difference between Floresta I and Ibitipoca III streams (different phytophysiognomies), but not between Floresta I and Ibitipoca I and Ibitipoca I and Ibitipoca II, which also have different phytophysiognomies. Besides this, the analysis showed a difference in the composition between two streams with the same phytophysiognomy (Ibitipoca I and Ibitipoca III).

\section{DISCUSSION}

The predominant species recorded in this study were from the Naididae family. Previous studies of the macrofauna associated with bryophytes have also found this family to be the main component of the oligochaete assemblage in this habitat (Percival and Whitehead, 1929; Habdija et al., 2004; Gorni and Alves, 2007; Rosa et al.,
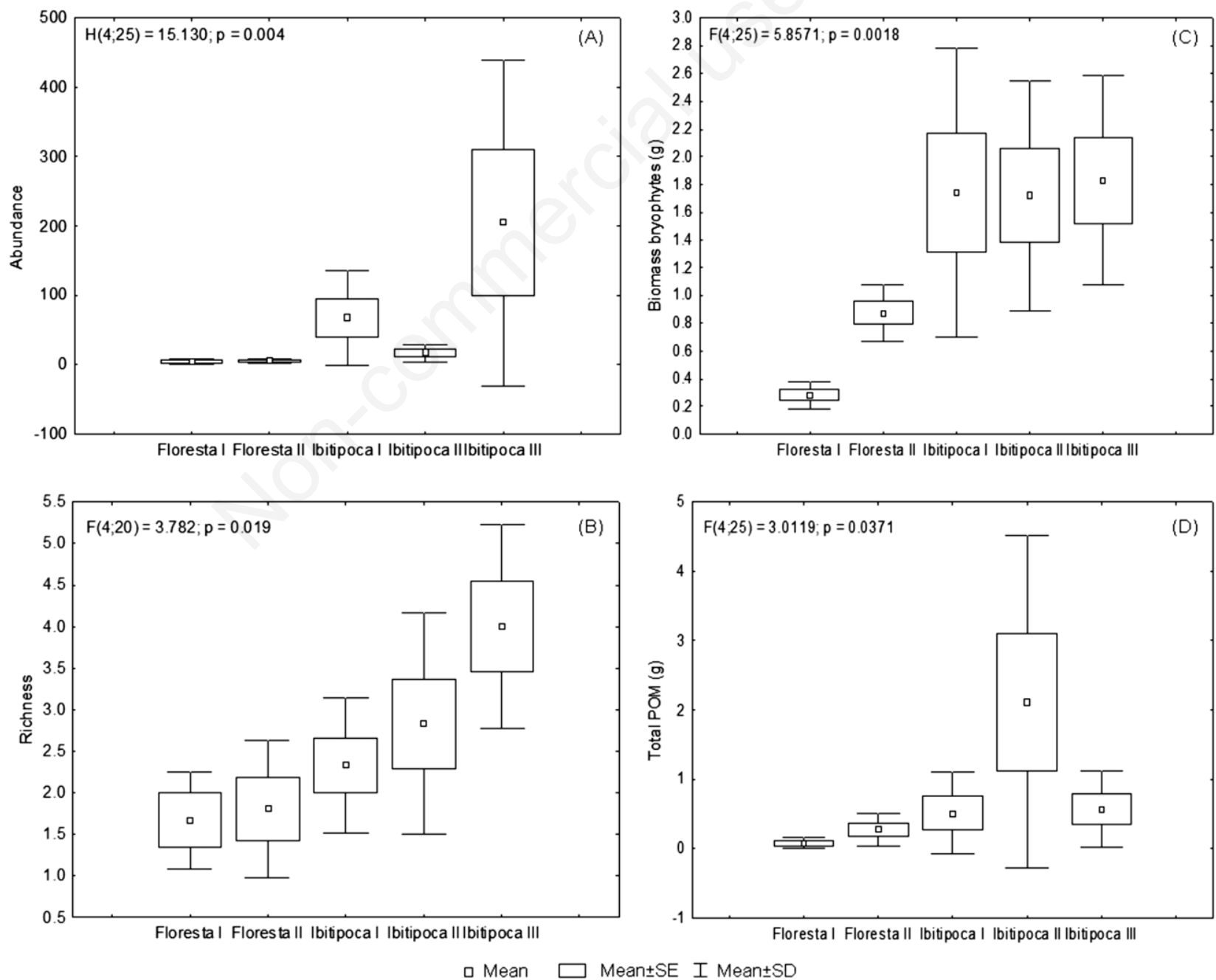

Fig. 1. Box plot for the values of abundance, richness, bryophyte biomass and particulate organic matter in the streams sampled in Fazenda Floresta and Ibitipoca State Park, Minas Gerais, Brazil.
2011). The Naididae are able to swim freely (Martin et al., 2008), favoring the exploitation of different habitats, such as bryophytes, where they find an abundant and steady source of food (Suren, 1992a).

Enchytraeidae is a cosmopolitan family (Martin et al., 2008), and in this study it presented the highest abundance in four of the five streams investigated. These oligochaetes are commonly found in bryophytes (Suren, 1993; Rosa et al., 2011; Glime, 2012) and are abundant in streams with well oxygenated water (Johnson and Ladle, 1989). The streams studied all fit this description, so this may have contributed to the presence of Enchytraeidae in the bryophytes analyzed. The species of oligochaetes collected in this study are also associated with other microhabitat types, such as fine sediments, sand and stones, in both riffles and pools (Schenková et al., 2001; Alves et al., 2008; Gorni and Alves, 2008; Behrend et al., 2009; Baturina, 
2012; Gorni and Alves, 2012; Rodrigues et al., 2013a). Hence, there are no indications that a particular species is restricted to inhabiting bryophytes.

Some studies have shown that the numerical abundance of invertebrates is associated with the availability of food resources. Suren and Winterbourn (1992) reported that the abundance of the majority of taxa identified in bryophytes was related to the quantity of periphyton or detrital biomass, while Habdija et al. (2004) found the density of invertebrates to be positively associated with the quantity of particulate organic matter retained in these plants. Linhart (2002) and Vlcková et al. (2002) also found

Tab. 3. Simple linear regression analysis of the relations between abundance, richness, total quantity of particulate organic matter and bryophyte biomass of streams in Fazenda Floresta and Ibitipoca State Park, Minas Gerais, Brazil. Values underlined are significantly different.

\begin{tabular}{|c|c|c|c|}
\hline & F & $\mathbf{P}$ & $\mathbf{R}^{2}$ \\
\hline \multicolumn{4}{|l|}{ Floresta I } \\
\hline POM x bryophyte biomass & $\underline{12.361}$ & $\underline{0.025}$ & $\underline{0.694}$ \\
\hline Abundance x POM & 0.072 & 0.794 & -0.227 \\
\hline Abundance $\mathrm{x}$ bryophyte biomass & 1.915 & 0.238 & 0.154 \\
\hline Richness x POM & 0 & 0.979 & -0.249 \\
\hline Richness $\mathrm{x}$ bryophyte biomass & 1.333 & 0.313 & 0.062 \\
\hline \multicolumn{4}{|l|}{ Floresta II } \\
\hline POM x bryophyte biomass & 2.686 & 0.175 & 0.252 \\
\hline Abundance x POM & 1.101 & 0.373 & 0.002 \\
\hline Abundance $\mathrm{x}$ bryophyte biomass & 0.013 & 0.911 & -0.246 \\
\hline Richness x POM & 2.055 & 0.224 & 0.174 \\
\hline Richness $\mathrm{x}$ bryophyte biomass & 0.872 & 0.594 & -0.026 \\
\hline \multicolumn{4}{|l|}{ Ibitipoca I } \\
\hline POM x bryophyte biomass & 25.480 & $\underline{0.008}$ & $\underline{0.830}$ \\
\hline Abundance $\mathrm{x}$ POM & $\underline{11.960}$ & $\underline{0.026}$ & $\underline{0.686}$ \\
\hline Abundance $\mathrm{x}$ bryophyte biomass & $\underline{7.527}$ & $\underline{0.050}$ & $\underline{0.566}$ \\
\hline Richness x POM & $\underline{12.545}$ & $\underline{0.024}$ & $\underline{0.697}$ \\
\hline Richness $\mathrm{x}$ bryophyte biomass & $\underline{6.923}$ & 0.051 & $\underline{0.542}$ \\
\hline \multicolumn{4}{|l|}{ Ibitipoca II } \\
\hline POM x bryophyte biomass & 0.133 & 0.730 & -0.209 \\
\hline Abundance x POM & 0 & 0.977 & -0.249 \\
\hline Abundance $\mathrm{x}$ bryophyte biomass & 0.186 & 0.687 & -0.194 \\
\hline Richness x POM & 1.518 & 0.285 & 0.094 \\
\hline Richness x bryophyte biomass & 0.118 & 0.743 & -0.214 \\
\hline \multicolumn{4}{|l|}{ Ibitipoca III } \\
\hline POM x bryophyte biomass & 0.083 & 0.780 & -0.224 \\
\hline Abundance x POM & 34.652 & $\underline{0.005}$ & $\underline{0.870}$ \\
\hline Abundance $\mathrm{x}$ bryophyte biomass & 0.020 & 0.886 & -0.243 \\
\hline Richness x POM & 0.051 & 0.824 & -0.234 \\
\hline Richness x bryophyte biomass & 1.243 & 0.328 & 0.046 \\
\hline
\end{tabular}

POM, particulate organic matter.

Tab. 4. Result of the Multi-Response Permutations Procedures (MRPP) between streams in Fazenda Floresta and Ibitipoca State Park. Values underlined are significantly different.

\begin{tabular}{llllrl} 
& & & T & A \\
Floresta I & $v s$ & Floresta II & 1.294 & -0.082 \\
Floresta I & $v s$ & Ibitipoca I & -1.868 & 0.927 \\
\hline Floresta I & $v s$ & Ibitipoca II & -0.535 & 0.03 \\
Floresta I & $v s$ & Ibitipoca III & -2.661 & 0.023 \\
\hline Floresta II & $v s$ & Ibitipoca I & -3.003 & 0.143 \\
Floresta II & $v s$ & Ibitipoca II & -0.799 & 0.105 \\
\hline Floresta II & $v s$ & Ibitipoca III & -4.229 & 0.029 \\
Ibitipoca I & $v s$ & Ibitipoca II & -1.180 & 0.014 \\
\hline Ibitipoca I & $v s$ & Ibitipoca III & -3.596 & 0.199 \\
Ibitipoca II & $v s$ & Ibitipoca III & -4.472 & 0.003 \\
\hline
\end{tabular}


a significant correlation between oligochaete abundance and amount of particulate organic matter. Although we found higher values for organic matter and numerical abundance in bryophytes in the streams in Ibitipoca State Park, the linear regression analysis showed that the oligochaete abundance was only related to the quantity of organic matter in Ibitipoca I and III streams. For the other streams, this relation was not significant, indicating that other factors, such as current speed and quantity of periphyton (not investigated in this study), might be related to the presence of oligochaetes in these plants (Habdija et al., 2004). The retention of detritus by bryophytes is related to their morphology and the entrance of allochthonous material in the aquatic system (Suren, 1992b). Percival and Whitehead (1929) observed higher oligochaete abundance levels where the concentration of mosses was higher. Suren (1993) reported significant relations between bryophyte biomass and density of invertebrates. The morphological and structural complexity provided by the diversity of aquatic plant species (Tokeshi and Arakaki, 2012), such as bryophytes, that occupy spaces on rocks that are near to each other is an important factor for maintenance of the species diversity of oligochaetes and other invertebrates. In the streams in Ibitipoca State Park, the presence of stones covered with a thicker carpet of bryophytes, thus having greater biomass, also contributed to the higher oligochaete richness values.

The species of oligochaetes identified in this study presented wide distribution and high adaptive capability to different environmental conditions. Although rocky field and seasonal semideciduous forest areas have different phytophysiognomies regarding the type of vegetation and geomorphological characteristics (e.g., soil and rocks), those differences were not sufficient or exclusive to the point of causing changes in the composition of oligochaetes, since we observed variation both within and between the two phytophysiognomies.

\section{CONCLUSIONS}

The results of this study show that despite the absence of significant pairwise relations between the bryophyte biomass, POM, abundance and richness of oligochaetes in all the streams, these organisms find favorable conditions to establish themselves among bryophytes, since these plants shelter an abundant and diverse fauna. Therefore, this work provides important information on the distribution of oligochaetes in preserved streams, besides demonstrating the ecological importance of aquatic bryophytes as habitat for invertebrates.

\section{ACKNOWLEDGMENTS}

We thank Andréa Pereira Luizi Ponzo, Ph.D., and Priscila de Souza Machado, M.Sc. of the Bryophyte Lab- oratory of Juiz de Fora Federal University for identifying the bryophytes and Juiz de Fora Federal University (Bolsa BIC) for financial support granted to the second author. We also thank the Minas Gerais State Research Support Foundation (FAPEMIG) for funding (CRA - APQ-0131212) and the National Council for Scientific and Technological Research (CNPq) for continued support (process 303156/2012-0).

\section{REFERENCES}

Alvarez M, Peckarsky B, 2013. The influence of moss on grazers in high-altitude streams: food, refuge or both? Freshwater Biol. 58:1982-1994.

Alves RG, Marchese MR, Martins RT, 2008. Oligochaeta (Annelida, Clitellata) of lotic environments at Parque Estadual Intervales (São Paulo, Brazil). Biota Neotrop. 8:21-25.

Baturina M, 2012. Distribuition and diversity of aquatic Oligochaeta in small streams of the middle taiga. Turk J. Zool. 36:75-84.

Behrend RDL, Fernades SP, Fujita DS, Takeda AM, 2009. Eight years of monitoring aquatic Oligochaeta from the Baía and Ivinhema Rivers. Braz. J. Biol. 69:559-571.

Brinkhurst RO, 1971. A guide for the identification of British aquatic Oligochaeta. $2^{\text {nd }}$ ed. Freshwater Biological Association Science Publisher.

Brinkhurst RO, Marchese MR, 1989. [Guía para la identificación de Oligoquetos acuáticos continentales de Sud y Centroamérica].[Book inn Spanish]. Asociación de Ciencias Naturales del Litoral, Santa Fe: 207 pp.

Buck WR, 1998. Pleurocarpous mosses of the West Indies. Mem. New York Bot. Gard. 82:1-440.

Frahm JP, 1991. Flora Neotropica Monograph 54- Dicranaceae: Campylopoidioideae, Paraleucobryoideae. New York. The New York Botanical Garden: 238 pp.

Glime JM, 2012. Invertebrates: Annelids. Chapt. 4-4. In: J.M. Glime, Bryophyte Ecology. vol. 2. Bryological Interaction. Ebook sponsored by Michigan Technological University and the International Association of Bryologists. Last updated 25 April 2012 and available at www.bryoecol.mtu.edu.

Glime JM, Clemons R, 1972. Species diversity of stream insects of Fontinalis spp. compared to diversity on artificial substrates. Ecology 53:458-464.

Gorni GR, Alves RG, 2007. Naididae (Annelida, Oligochaeta) associated with bryophytes in Brotas, State of São Paulo, Brazil. Rev. Bras. Zool. 24:518-519.

Gorni GR, Alves RG, 2008. Oligochaeta (Annelida: Clitellata) em riachos de baixa ordem do Parque Estadual de Campos do Jordão (São Paulo-Brasil). Biota Neotrop. 8:161-165.

Gorni GR, Alves RG, 2012. Oligochaetes (Annelida, Clitellata) in a neotropical stream: a mesohabitat approach. Iheringia Ser. Zool. 102:106-110.

Gradstein SR, Costa DP, 2003. The Hepaticae and Anthocerotae of Brazil. Mem. New York Bot. Gard. 87:1-318.

Habdija I, Habdija BP, Matoničkin M, Kučinić IM, Radanović I, Miliša M, Mihaljević Z, 2004. Current velocity and food supply as factors affecting the composition of macroinvertebrates in bryophyte habitats in karst running water. Biol. Bratislava 59:577-593. 
Johnson P, Ladle M, 1989. The Enchytraeidae (Oligochaeta) of streams of Southern England. Ann. Limnol. 25:121-129.

Linhart J, Vlcková S, Uvíra V, 2002. Bryophytes as a special mesohabitat for meiofauna in a rip-rapped channel. Riv. Res. Appl. 18:321-330.

Mccune B, Mefford MJ, 2006. PC-ORD. Multivariate Analysis of Ecological Data. Version 5.10. MjM Software, Gleneden Beach, US.A

Martin P, Martinez-Ansemil E, Pinder A, Timm T, Wetzel MJ, 2008. Global diversity of oligochaetous clitellates ("Oligochaeta"; Clitallata) in freshwater. Hydrobiologia 589:117-127.

Parker J, Burkepile D, Collins D, Kubanek J, Hay M, 2007. Stream mosses as chemically-defended refugia for freshwater macroinvertebrates. Oikos 116:302-312.

Percival E, Whitehead H, 1929. A quantitative study of the fauna of some types of stream-bed. J. Ecol.17:282-314.

Pursell RA, 2007. Flora Neotropica Monograph 101 - Fissidentaceae. The New York Botanical Garden, New York: 278 pp.

Reynolds JW, Wetzel MJ, 2014. Nomenclatura Oligochaetologica- A catalogue of names, descriptions and type specimens. Editio Secunda. Available from: http://wwx.inhs.illinois.edu/ people/mjwetzel/nomenoligo (accessed: 27/02/2015).

Righi G, 1984. [Manual de identificação de invertebrados límnicos do Brasil].[Book in Portuguese]. CNPq/Coordenação Editorial, Brasília: 48 pp.

Rodrigues LFT, Leite FS, Alves RG, 2013a. Inventory and distribution of Oligochaeta (Annelida, Clitellata) in first-order streams in preserved areas of the state of Minas Gerais, Brazil. Biota Neotrop. 13:245-254.

Rodrigues LFT, Santana LD, Alves RG, 2013b. Aquatic oligochaetes associated with bryophytes in an Atlantic Forest stream. Biota Neotrop. 13:371-375.

Rosa BFJV, Silva MVD, Oliveira VC, Martins RT, Alves RG, 2011. Macroinvertebrates associated with bryophyte in a firstorder Atlantic Forest stream. Rev. Bras. Zool. 28:351-356.
Rosa BFJV, Silva MVD, Alves RG, 2013. Composition and Structure of the Chironomidae (Insecta: Diptera) Community Associated with Bryophytes in a First-Order Stream in the Atlantic Forest, Brazil. Neotrop. Entomol. 42:15-21.

Schenková J, Komárek O, Zahrádková S, 2001. Oligochaeta of the Morava and Odra River Basins (Czech Republic): species distribution and community composition. Hydrobiologia 463:235-240.

Sharp AJ, Crum H, Eckel PM, 1994. The moss flora of Mexico. Memoirs of the New York Botanical Garden 69:1-1113.

Statsoft, 2004. Statistica: data analysis software system, ver. 7. Available from: http://www.statsoft.com.

Stream Bryophyte Group, 1999. The role of Bryophytes in stream ecosystens. J. N. Am. Benth. Soc. 18:151-184.

Suren AM, 1991. Assessment of artificial bryophytes for invertebrate sampling in two New Zealand alpine streams. New Zeal. J. Mar. Freshwater Res. 25:101-112.

Suren AM, 1992a. Enhancement of invertebrate food resources by bryophytes in New Zealand alpine headwater streams. New Zeal. J. Mar. Freshwater Res 26:229-239.

Suren AM, 1992b. Meiofaunal communities associated with bryophytesand gravels in shaded and unshaded alpine streams in New Zealand. New Zeal. J. Mar. Freshwater Res. 26:115-125.

Suren AM, Winterbourn MJ, 1992. The influence of periphyton, detritus and shelter on invertebrate colonization of aquatic bryophytes. Freshwater Biol. 27:327-339.

Suren AM, 1993. Bryophytes and associated invertebrates in first-order alpine streams of Arthur's Pass, New Zealand. New Zeal. J. Mar. Freshwater Res 27:479-494.

Tokeshi M, Arakaki S, 2012. Habitat complexity in aquatic systems: fractals and beyond. Hydroiologia 685:27-47.

Vlčková S, Linhart J, Uvíra V, 2002. Permanent and temporary meiofauna of an aquatic moss Fontinalis antipyretica Hedw. Acta. Univ. Palacki. Olomuc. 39:131-140. 